Abstract

Ayman al-Zawahiri and his allies have focused on the excessive violence perpetrated by ISIS, and sought to present al-Qaeda as a more moderate alternative.

Ayman al-Zawahiri's leadership of al-Qaeda has been beset by a series of calamities that threaten the viability of the movement's core group and its legacy. Zawahiri was always more suited to be second in command, offering dense strategic and ideological deliberations rather than acting as the public face of a global Islamist militant movement. Replacing the charismatic Osama bin Laden was thus always going to be a challenge. The fact that secular Arab rulers, especially in Egypt (Zawahiri's native land and a consistent preoccupation of his), have been toppled on his watch through popular uprising and military intervention - as opposed to jihadist coercion - has further undermined Zawahiri's position as al-Qaeda leader. The Arab Spring uprisings demonstrated the success of regime-change methods that al-Qaeda had consistently dismissed, while removing some of the main protagonists of its grievance narrative.

As the Arab revolutions unfolded, al-Qaeda's propaganda machine immediately set to work portraying them as half-baked, hijacked, derailed or ultimately misguided. The aftermath of the revolutions in Egypt and beyond quickly offered plenty of examples to back up this narrative. The involvement of other jihadist movements in the turmoil surrounding the uprisings, however, quickly became an even greater challenge for the group's leaders. As jihadists became an increasingly prominent component of the Syrian civil war, it became clear that al-Qaeda was not the leading force among them. Instead, al-Qaeda's former Iraqi offshoot, led by Abu Bakr al-Baghdadi, created the Islamic State of Iraq and al-Sham (ISIS) in April 2013 and later declared an Islamic 'caliphate' in Iraq, thus presenting a potent jihadist alternative that was seen to have produced more tangible results in a few years than alQaeda had managed in two decades. Al-Qaeda's ability to challenge the status quo, and to direct the way forward, was badly damaged.

Al-Qaeda's war of words

To respond to the challenge of ISIS, al-Qaeda and its friends and allies have adopted a twopronged communications strategy intended, firstly, to remind the world of the group's ongoing relevance and position at the pinnacle of global jihad; and, secondly, to delegitimise ISIS (now commonly referred to as the 'Islamic State') as a jihadist entity. Core al-Qaeda's September 2014 announcement of a new franchise in South Asia (covering Myanmar, Bangladesh and Indian provinces with large Muslim populations), for instance, formed part of this strategy. The message was both global, emphasising that al-Qaeda remains a global player, and local, conveying the group's awareness of the needs of Muslims in these areas and the threat of secularism and Hindu nationalism to Pakistan.

More explicitly, Zawahiri insisted in a statement published more than a year after the creation of ISIS that the group was a 'branch affiliated to al-Qaeda' and that its 'leader and 
soldiers pledge their loyalty to al-Qaeda ... and their leader Sheikh Osama Bin Laden, may God rest his soul in peace, and then myself after him'. Zawahiri, as 'emir' of al-Qaeda, had, he insisted, received correspondence from Baghdadi in which the latter reiterated his respect for and loyalty to the former as overall leader. As a result, according to Zawahiri, any pledges of allegiance to Baghdadi would be null and void. ${ }^{-1}$ Al-Qaeda was still in charge. This message was reinforced in the first edition of the group's new online newsletter An-Nafeer, in which its leaders reiterated their allegiance to the leader of the Afghan Taliban emirate, Mullah Omar, highlighting the system of allegiance that bin Laden had embraced, and implicitly emphasising Baghdadi's subservient position within this relationship. ${ }^{2}$

Yet even as they have insisted that ISIS members remain their subordinates, al-Qaeda leaders have pursued an alternative - and seemingly contradictory - strategy intended to highlight those aspects of their world-view and goals that supposedly differentiate al-Qaeda from Baghdadi's cohorts. Two themes that had begun to feature in al-Qaeda communications before the creation of ISIS became more prominent once the latter began to gain ground. Firstly, in light of al-Qaeda's material weakness compared with the vast resources of ISIS, Zawahiri has sought to highlight the more ideational and normative aspects of al-Qaeda rather than its organisational components. In his 2011 eulogy to bin Laden, Zawahiri presented al-Qaeda as more of a concept that Islamist militants had embraced than a structured group. This theme has now been developed further. 'What we share in terms of faith and jihad rises far above groups and parties,' Zawahiri argued in his October 2013 appeal to the people of Syria..$^{3}$ Likewise, in his seventh 'interview' with alQaeda's propaganda wing As-Sahab, released in spring 2014, he insisted, 'Al-Qaeda is a mission before it is an organisation or group and, in this sense, it is expanding more.'

Secondly, Zawahiri and his allies have focused on the excessive violence perpetrated by ISIS, and sought to present al-Qaeda as a more moderate alternative. Over the years, the group's rhetoric concerning the indiscriminate use of violence has evolved. At first, great emphasis was placed on justifying multiple civilian deaths following major attacks, such as 9/11 and the 2005 London bombings. Later, the excessive use of violence against Muslims by Abu Musab al-Zarqawi and his successors in Iraq, and by affiliates and allies in Pakistan, prompted al-Qaeda leaders to warn against mass-casualty attacks that could be construed as extra-legal within the context of militant Islamism. This theme has become particularly prominent in al-Qaeda's public messaging since the rise of ISIS.

In his seventh interview with As-Sahab, for example, Zawahiri argued that the principal difference between al-Qaeda and ISIS concerned their divergent opinions regarding methods and approaches to jihad. Al-Qaeda focused its wrath on the US and its allies, Zawahiri claimed, rather than 'peripheral battles'. Furthermore, al-Qaeda's approach emphasised 'the preservation of blood': 'operations are avoided in which blood is shed without justification in the markets and the residential areas. ${ }^{\prime}$ These tactical priorities were 
set out in al-Qaeda's 'General Guidelines for the Work of a Jihadi', released in September 2013.

The key issue for Zawahiri, which he seemed to elevate even above legal concerns, was the need to respect public opinion. Thus, Zawahiri warned in his As-Sahab interview:

We would like to advise our brothers that in order to succeed any armed opposition must mobilise public support. Experience has shown that without this support combat does not turn into victory or success. Thus they must avoid any action, and even though it may be legal they should abandon it, if it should alienate the Ummah from them. ${ }^{7}$

Zawahiri's publication record reveals further evidence of this preoccupation with limiting the excesses of jihad. Indeed, he was warning about the dangers of alienating the public as early as 2001, the year his memoir, Knights Under the Banner of the Prophet, was first released. In that volume, he reflected on how the death of Shayma Abdel-Halim, an 11-yearold schoolgirl killed in a bomb blast targeting the Egyptian prime minister, resulted in public denunciation of his Egyptian Al-Jihad organisation..$^{-}$More than ten years later, in October 2013, al-Qaeda released the second edition of Zawahiri's book Scent of Paradise, which is dedicated to defending and promoting the use of martyrdom operations. This edition, published to the Internet nine years after the first version was released, added caveats limiting the scope and focus of suicide tactics. Zawahiri wrote in the introduction that an 'increase in martyrdom operations has been accompanied by some deviation and exaggeration which must be corrected and admitted to'. At times, Zawahiri complained, groups employing 'martyrdom' operations had taken no precautions to protect innocent lives, or chosen targets and methods of attack that alienated the public. Zawahiri did not mention ISIS specifically, but his cautionary tone revealed his desire to present al-Qaeda's approach to jihad as less extreme, and therefore more sustainable, than other approaches on offer.

\section{Resisting the khawarej}

Unfortunately for him, Zawahiri's efforts to delegitimise ISIS have been weakened by the latter organisation's ability to appeal to regional militant groups in Egypt, Libya and even South Asia. Such groups have sought to capitalise on ISIS's momentum by rebranding their organisations as 'provinces' of the Islamic State. ${ }^{-}$The extent of Zawahiri's isolation became embarrassingly clear when his letter regarding the rift between ISIS and Jabhat al-Nusra, an al-Qaeda affiliate in Syria, was made public in June 2013, revealing not only that both organisations were operating independently of the al-Qaeda leader's advice, but also that the 'emir' had only learnt of the creation of ISIS and of the spat with the al-Nusra Front via the mainstream news media. Zawahiri's letter contained a 15-point reconciliation 'roadmap' ordering ISIS to be disbanded and giving Baghdadi 12 months to prove himself as al-Qaeda's deputy in command of the Iraqi franchise - orders which have obviously been ignored. $\underline{10}$ 
Public and private arbitration efforts have since failed, as have attempts at top-down conditioning and control.

Yet, even as various al-Qaeda affiliates have expressed sympathy towards ISIS, several other jihadist veterans and ideologues have come out in strong opposition to the way it conducts jihad. The criticism from Abu Muhammad al-Maqdisi, an influential jihadi theorist, is probably most important. Maqdisi has issued several statements condemning ISIS leaders for their brutality, their indiscriminate violence and, in particular, their reluctance to accept Zawahiri's authority and to engage with his mediation efforts. In May 2014, Maqdisi declared ISIS a 'deviant organisation' that had strayed from truth to a path of aggression and disobedience..$^{11}$ In an explanatory note accompanying the declaration, Maqdisi accused ISIS of peddling 'lies, ignorance, tyranny and falsification'. More notably, Maqdisi claimed that ISIS representatives had admitted in their correspondence with him to having members within their ranks who could best be described as khawarej..$^{12}$

The khawarej (Kharijites, in English) were a group of zealots who abandoned their caliph, Ali ibn Abi Talib, after he sought to negotiate a truce with his rival, Mu'awiya I, and his Syrian allies following the Battle of Siffin, which took place near the Euphrates River in July 657CE. The truce agreement was meant to represent God's will, but was negotiated by men, which angered those who sought to implement the Koran directly. Those who rebelled and seceded (kharaja) from 'Ali's authority in protest have since come to represent any extremist, fringe movement obsessed with doctrinal purity and the notion of excommunication (takfir) in Islam. $\underline{13}$ Indeed, referring to the khawarej has become a common rhetorical tool to delegitimise Islamic entities that are deemed to be excessive or to constitute a threat to the established order. The label has, for instance, been applied to major organisations such as the Muslim Brotherhood, $\underline{14}$ as well as to Maqdisi himself, $\underline{15}$ in order to represent them as dangerous and illegitimate.

\section{ISIS declared all opponents unbelievers}

Now, Maqdisi has applied the khawarej label to ISIS, doing so in the context of an extensive response to a recent question posted on his influential website, tawhed.ws. The apparently unsolicited query concerned the extent to which Muslims could seek assistance from apostates and atheists to kill the khawarej, or to provide information about them in order to prevent them from causing harm. In his response, Maqdisi emphasised how ISIS members had declared all those who opposed the organisation or its methods unbelievers, thus going too far in their application of the concept of excommunication, which renders subjects apostates and justifiable targets of violence. Those who participated in suicide bombings under this pretext, Maqdisi warned, would not be considered martyrs or receive their rewards in heaven. Making explicit references to ISIS, he cautioned against 'the confusion of using the religion as a method to settle accounts and to bring victory to one side over another or for some group or organisations'. Moreover, he argued that, although collaborating with apostates would normally be prohibited, Muslims who sought assistance 
from apostate governments to fight against the oppression of the khawarej would not be condemned. $\underline{16}$

ISIS is not the first jihadist 'fringe operator' to become the focus of stark criticism and even denunciation from within more established jihadist circles. Prominent ideologues such as Abu Qatada, who has issued statements condemning ISIS, were forced in the past to reconsider their staunch support for the Algerian Armed Islamic Group (GIA) due to its excesses. ${ }^{17}$ Indeed, former public supporters of the GIA, such as Abu Hamza al-Masri, who rose to notoriety during his brief spell at Finsbury Park Mosque in London, eventually denounced the GIA as modern-day Kharijites. Hamza even wrote a book titled The Khawaarij and Jihad, in which he described the GIA as neo-Kharijites that had become obsessed with excommunication and the wanton targeting of protected people. The GIA had revolted against the core tenets of Islam, Abu Hamza argued, just as the original Kharijites had done during the reign of 'Ali ibn Abi Talib. $\underline{\text { 18 }}$

Today, many analysts see parallels between the eventual jihadist denunciation of the GIA and the current wave of Islamist criticism, including from some of the same ideologues, aimed at ISIS. $\frac{19}{-1}$ Indeed, al-Qaeda itself has presented ISIS in similar terms. In a thinly veiled threat aimed at the ISIS leadership, Zawahiri, in his seventh interview with As-Sahab, warned those who had rebuffed his efforts to reconcile competing jihadist factions in Iraq and Syria that they risked losing all public support. Those who encouraged strife and avoided reconciliation, he cautioned, contributed indirectly to the deaths of the mujahideen and would be punished both in the temporal world and the afterlife. Such a loss of legitimacy was a very serious matter, he insisted. After all, when the GIA in Algeria suffered this fate, it ceased to operate. The same happened to warring factions in Afghanistan following Russia's withdrawal in 1989. Their excesses, greed and obstinacy led to their ultimate destruction. By contrast, Zawahiri argued, when juristic authorities and the general public bestowed legitimacy on the Taliban, they emerged victorious. ${ }^{20}$

Zawahiri insisted his remarks were not directed against a specific organisation - before going on to address another question in this choreographed interview, directed specifically at ISIS. Asked to clarify why the al-Qaeda leadership had initially supported Baghdadi's group before changing its stance, Zawahiri responded: 'My brothers and I were praising the good which was in it, and we were trying to improve that which was not thus with advice and direction and orders, but we could not. ${ }^{21}$ ISIS, therefore, was a lost cause, an arrogant and extremist entity that was bound to fail.

Zawahiri took pains in the interview to emphasise that the caliphate envisaged by al-Qaeda would be inclusive and righteous, in apparent contrast to the ISIS 'caliphate' in parts of Iraq and Syria. 'Our approach,' he insisted, is 'to bring together the Ummah and to unify it around the message of unity, and [to] work towards the return of the rightly guided caliphate which is founded on the consultation and agreement of Muslims.' 'We could not,' he continued, 'join the Ummah together if our vision was a vision [of] absolute power over 
it, the usurper of its rights, committing aggression towards it, or the overpowering of it. $\underline{22}$ Baghdadi and his followers, by contrast, were failing to listen to the voice of reason. $\underline{23}$ Their rise to power, Zawahiri lamented, had led to great fitna, infighting, amongst the mujahideen, and there was now great danger that the fruits of jihad would be lost before they had ripened. $\underline{24}$

Chinks in the armour

Al-Qaeda's efforts to promote itself and to delegitimise ISIS seem at first to be a sign of desperation; the group's organisational weaknesses forced its leaders to develop a narrative to ensure its continued relevance. The leadership opted to frame the movement as an intangible, ideational project that exists independently of, and that will outlive, its present office-holders. This representation of al-Qaeda as a more decentralised and abstract entity has been prominent in descriptive and analytical accounts of the movement for years, but had previously been broadly resisted or qualified in the group's own discourse. It is notable that this representation has now been embraced by al-Qaeda itself in response to the rise of ISIS.

Yet desperation is not the sole driver of al-Qaeda's reconceptualisation. As noted, al-Qaeda leaders have over the years become acutely aware of the need to consider public opinion, at least with respect to those potentially sympathetic towards its version of revolutionary Salafism. As ISIS has emerged as an entity separate from al-Qaeda, its excesses have served to divert attention away from the excesses for which its erstwhile parent organisation has been responsible. Extremism is by definition a relative concept, and within the context of militant Islam, al-Qaeda now has the opportunity to present itself as the 'moderate', 'mainstream' option. Indeed, Zawahiri has attempted to seize this opportunity by emphasising the limitations on jihad, and the extent to which targets should be specific and qualified, and any violence limited. These efforts may ultimately fail, and al-Qaeda may yet fall into obscurity, but there is also the chance that, despite its lack of organisational capacity and tangible gains, the 'al-Qaeda central' mode of jihad will come to be seen more favourably than the ISIS mode in the long term.

There is another element of al-Qaeda's apparent weakness vis-à-vis ISIS that might ultimately prove to be an advantage. Al-Qaeda has never realised its goal of establishing a caliphate or controlling territory. ISIS, on the other hand, has achieved both remarkably quickly by exploiting the turmoil in Syria and the failures of sectarian governance in Iraq. Now that it must act as a kind of government, however, ISIS is encountering numerous practical challenges that al-Qaeda has never had to confront. These challenges - of day-today governance and territorial control - are arguably greater than any problems al-Qaeda currently faces owing to its failure to establish a caliphate of its own. Populist political parties often thrive in opposition but change beyond recognition once they enter government and are forced to compromise or make unpopular decisions. Although there is 
much that distinguishes ISIS from such political entities, it nevertheless faces similar conundrums.

Whatever happens now, it is clear that the emergence of ISIS as a jihadist entity separate from al-Qaeda - and al-Qaeda's response to it - has raised important questions about the future of militant Islam. Perhaps the most urgent of these concerns how recent developments might affect or inform efforts to counter the jihadist threat. Three key themes to emerge from alQaeda's rhetorical response to the rise of ISIS seem relevant to this question: the jihadist need for wider support; the notion of unity among jihadists as a way to attract followers; and the importance of conveying a consistent message to potential followers. All three point to ways the threat of transnational jihadism might be challenged.

Quintan Wiktorowicz, among others, has noted that no militant Islamic movement can survive for long without mobilising at least part of its target community of potential participants and supporters. ${ }^{25}$ ISIS has thrived not only because of its material strength and ruthless tactics but also because it has responded to concerns of Sunnis in Iraq, Syria and elsewhere, who feel their way of life is under threat. Any use of force against ISIS targets, therefore, needs to be accompanied by a set of measures designed to protect the interests of disenfranchised Sunnis. Moreover, given that both ISIS and al-Qaeda will seek to present any such military efforts as a form of aggression requiring further mobilisation in defence of Islam, it will be necessary to carefully articulate the ways in which combat operations against jihadists in Syria and Iraq differ from those of the Iraq War. Such differences include not just the targets of the military campaign, but also the softer and more holistic approach that has been adopted to respond to the crisis. The British government, for instance, has offered $\mathrm{f} 700$ million in humanitarian aid to help those affected by the war in Syria, ${ }^{26}$ double the likely cost of military strikes against ISIS, based on the current scope of operations. ${ }^{27}$ Indeed, the UK and the US are by far the most generous humanitarian-aid donors to have responded to the Syria crisis. $\frac{28}{\text { The }}$ The countries and their allies need to be as savvy at presenting themselves - their goals, strengths and achievements - to their target audiences as their adversaries have been.

Inconsistencies in the jihadists' own messages can be used against them. For instance, the two contemporary analogies that Zawahiri himself has drawn in relation to ISIS and the current situation in Syria and Iraq - those of the fitna that followed regime change in Afghanistan in the early 1990s, and the case of the GIA during the Algerian Civil War - point to the conclusion that any notion of jihadi unity is purely rhetorical, and unsustainable in the real world. Similarly, Zawahiri's response to the rise of ISIS appears to validate the importance of top-down organisation, even as he claims to champion a more diffuse, ideational approach. Through emphasising the subordinate position of the ISIS leadership to al-Qaeda, Zawahiri has displayed a clear appetite for hierarchy and control within the alQaeda framework. Yet, at the same time, he has, reactively, presented al-Qaeda as a mere 'movement' or 'mission' embedded within a much larger framework of jihad, in which the 
presence of any particular group of leaders is irrelevant. Zawahiri's recent insistence on protecting minorities and limiting violence, intended to accentuate the apparent difference between ISIS and al-Qaeda, also contradicts his earlier attempts to articulate justifications for indiscriminate targeting. $\underline{29}$ These contradictions represent a weakness that could be exploited. $\underline{30}$

Transnational jihadi groups might have the momentum in Iraq and Syria at the moment, but they are far from united. ISIS, the most popular among them, has displayed such barbarity that al-Qaeda's prediction that it will eventually implode may well prove accurate. Meanwhile, al-Qaeda's own fractionalisation continues apace, and has even been implicitly acknowledged in the group's own rhetoric. Neither group is as invulnerable as it would have the world believe.

Notes

1 Ayman al-Zawahiri, 'Answers to the Esteemed Shaykhs', statement issued by As-Sahab, 24 May 2014, http://just-paste.it/fldu.

2 'O Victorious Ummah, Carry Your Arms, Wage Jihad, and Rejoice', An-Nafeer, vol. 1, no. 1, July 2014, published by As-Sahab.

3 Ayman al-Zawahiri, 'Tawhid in the Face of Tyrants', statement issued by As-Sahab, 14 October 2013, https://archive.org/details/tw.m.tagout.

4 Ayman al-Zawahiri, 'The Seventh Interview with Sheikh Ayman al-Zawahiri', interview issued by As-Sahab, 18 April 2014, http://jihadology.net/2014/05/02/assa\%E1\%B8\%A5abmedia-presents-a-new-video-message-from-al-qaidahs-dr-ayman-al-\%E1\%BA\%93awahirithe-seventh-interview-the-reality-between-pain-and-hope/.

5 Ibid.

6 Ayman al-Zawahiri, 'General Guidelines for the Work of a Jihadi', statement issued by AsSahab, 14 September 2013, https://archive.org/details/JihadGuidelines.

7 Al-Zawahiri, 'The Seventh Interview with Sheikh Ayman al-Zawahiri'.

8 Ayman al-Zawahiri, Knights under the Banner of the Prophet, initially published in Al-Sharq al-Awsat, 2 December 2001, available in translation from the Foreign Broadcast Information Service.

9 'Islamic State Builds on al-Qaeda Lands', BBC, 30 January 2015, http://www.bbc.co.uk/news/world-31064300.

10 Basma Atassi, 'Qaeda Chief Annuls Syrian-Iraqi Jihad Merger', Al-Jazeera, 9 June 2013, www.aljazeera.com/news/middlee-ast/2013/06/2013699425657882.html; Ayman alZawahiri, untitled letter, published by Al-Fajr, 9 June 2013. 
11 Abu Muhammad al-Maqdisi, 'A Call to the Ummah \& Mujahideen', May 2014, http://www.justpaste.it/ Maqdisi-ISIS.

12 Abu Muhammad al-Maqdisi, 'Explanatory Appendix Confirming Statement (1)', 26 May 2014, http://tawhed.ws/r?i=26051401.

13 See Hussam S. Timani, Modern Intellectual Readings of the Kharijites (New York: Peter Lang Publishing, 2008).

14 See Fazlur Rahman, Islam, 2nd ed. (Chicago, IL: University of Chicago Press, 1979); and Malise Ruthven, Islam in the World (Oxford: Oxford University Press, 1984).

15 Nelly Lahoud, 'In Search of Philosopher-jihadis: Abu Muhammad al-Maqdisi's Jihadi Philosophy', Totalitarian Movements and Political Religions, vol. 10, no. 2, June 2009, pp. 205-20.

16 Abu Muhammad al-Maqdisi, 'Q. 487 What is the Rule of Seeking Assistance from Atheists and Apostates to Kill the Khawarej and What is the Rule of Informing on Them So We Prevent Their Harm?', July 2014, http://www. tawhed.ws/FAO/pr?qid=487\&PHPSESS ID=83fbee0bf3f1a89cda330096755c9f07.

17 Thomas Joscelyn, 'Abu Qatada Provides Jihadists with Ideological Guidance from a Jordanian Prison', Long War Journal, 30 April 2014, http://www. longwarjournal.org/archives/2014/04/jihadist_ideologue_p.php.

18 Abu Hamza al-Masri, The Khawaarij and Jihad, Ibn Umar (ed.), publisher and date unknown, once available via Abu Hamza's Finsbury Park network.

19 See, for example, Aaron Y. Zelin, 'Al-Qaeda Disaffiliates with the Islamic State of Iraq and al-Sham', Washington Institute, 4 February 2014, http://www.washingtoninstitute.org/policy-analysis/view/al-qaeda-disaffiliates-with-the-islamic-state-of-iraq-and-alsham.

20 Ayman al-Zawahiri, 'The Seventh Interview with Sheikh Ayman al-Zawahiri'.

21 lbid.

22 Ibid.

23 Ayman al-Zawahiri, 'Answers to the Esteemed Shaykhs'.

24 Ayman al-Zawahiri, 'The Seventh Interview with Sheikh Ayman al-Zawahiri'.

25 Quintan Wiktorowicz, Islamic Activism: A Social Movement Theory Approach (Bloomington, IN: Indiana University Press, 2014), p. 15. 
26 Foreign and Commonwealth Office, 'Syria Crisis: Latest Updates on UK Aid', 11 November 2014, https:// www.gov.uk/government/news/ syria-the-latest-updates-on-uk-aid.

27 Ivana Kottasova, 'How Much Will It Cost Britain to Bomb ISIS?', CNN, 29 September 2014, http://edition. cnn.com/2014/09/26/business/uk-iraq-airstrikes-cost/.

28 Joel Gunter and Nassos Stylianou, 'Syria Crisis: How Does Britain's Aid Donation Compare?', Telegraph, 15 January 2014, http://www.telegraph. co.uk/news/worldnews/middleeast/ syria/10570726/Syria-crisis-how-does-Britains-aiddonation-compare.html.

29 Contrast, for example, Zawahiri's elaboration of the justifications for killing noncombatants in Exoneration: A Letter Exonerating the Ummah of the Pen and the Sword from the Unjust Allegation of Feebleness and Weakness (As-Sahab, 2008) and the caveats in 'General Guidelines for the Work of a Jihadi' (As-Sahab, 2013).

30 On the importance of empirical credibility to any message intended to mobilise supporters, see David A. Snow and Robert D. Benford, 'Ideology, Frame Resonance, and Participant Mobilization', International Social Movement Research, vol. 1, 1988, pp. 197217. 